\title{
Chapter 13 \\ Bad Practice in Erosion Management: The Southern Sicily Case Study
}

\author{
Giorgio Anfuso, José Ángel Martínez-del-Pozo, and Nelson Rangel-Buitrago
}

\begin{abstract}
This case study from Sicily illustrates a common sequence of events where one unwise action was countered with another, which in turn created additional problems. The situation arose through strong political interference and ignorance (or lack of concern) regarding the environmental impacts of human interventions on the shoreline and by the public perception that government has a duty to protect private property. The poor design and location of ports and harbours produced infilling problems and huge updrift accretion with concomitant downdrift erosion. The human-induced coastal retreat was counteracted by the progressive emplacement of breakwaters creating a "domino" effect. On many occasions these were constructed to protect unplanned and illegal (in the sense that they do not conform to planning regulations) beachfront summer houses. Without the presence of these structures, there would have been no need for publicly funded intervention.

Furthermore, only a narrow coastal belt close to the shoreline is used by bathers on the wide beaches formed updrift of ports and harbours and in the lee of breakwaters, most of the accreted beach being unused or partially occupied by tourist developments. Thus beach users and municipalities acquired some benefits from beach accretion at specific sites, the opposite being true in eroding areas.
\end{abstract}

\footnotetext{
G. Anfuso $(\bowtie) \cdot$ N. Rangel-Buitrago

Dpto. Ciencias de la Tierra, Facultad de Ciencias del Mar y Ambientales, Universidad de Cádiz, Polígono Río San Pedro s/n, Puerto Real 11510, Spain

e-mail: giorgio.anfuso@uca.es; nelson.rangelbuitrago@mail.uca.es
}

J.Á. Martínez-del-Pozo

Instituto de Arqueología de Mérida - CSIC, Plaza de España, 15, Mérida (Badajoz) 06800, Spain e-mail: jangel.martinez@iam.csic.es 


\subsection{Introduction}

Coastal occupation has been increasing in the past few decades especially due to coastal tourism-related activities. Tourism is now one of the world's largest industries (Klein et al. 2004; Jones and Phillips 2011). In the Mediterranean region tourism is the most important activity with 298 and 400 million international and domestic tourist arrivals in 2008. The fastest rates of coastal development between 1990 and 2000 occurred in Portugal (34\%), Ireland (27\%), Spain (18\%), followed by France, Italy and Greece (EEA 2006). In several coastal regions of Italy, France and Spain, the coverage of built-up areas in the first kilometre coastal strip exceeds $45 \%$ and, in these areas, further development is occurring in the coastal hinterland. Spain plus Italy, France, Greece and Turkey account for 'the most significant flow of tourists.... a sun, sea and sand (3S) market' (Doods and Kelman 2008) and tourism is expected to grow at a level of $4.0 \%$ per year over the next 10 years. The European Union offers a vast market in its colder and affluent northern parts and the capacity for growth is viewed as almost unlimited.

Associated with ongoing tourism development in Europe is the high level of armouring of shorelines by coastal defences and harbours (EEA 2006), with especially high percentages of armoured shoreline in the North Sea (16\%) and the Mediterranean Sea (more than $8 \%$ ). The protection of built-up areas and halting of shoreline recession have largely been carried out through the construction of hard defence structures, which mainly consist of groins, jetties, breakwaters, revetments and seawalls. Beach nourishment works are common (Hanson et al. 2002; Cooper and Alonso 2006). In recent decades coastal armouring has also accompanied the construction of marinas for tourism purposes and harbours and ports for commercial activities. In this sense, Italy and the United Kingdom received the most vessel arrivals in terms of tonnage during 2003.

In many localities, arable land has also been lost to intensive agricultural activities, e.g. in the southern regions of Italy, Greece and Cyprus and the Levante in Spain, and urban development, which is especially driven by higher land prices in areas adjacent to existing settlements.

A common problem associated with coastal armouring is the "coastal squeeze" (Doody 2004), which takes place when a coastline is prevented from its landward migration by seawalls or other man-made structures. Coastal erosive processes associated with sea level rise and increasing storminess can cause the complete disappearance of the beach or salt marshes and deepening of nearshore areas fronting coastal structures (Pilkey and Dixon 1996; Doody 2004). Other, less immediately obvious examples of decreased ability to respond to changes occur when coastal defences at the base of eroding cliffs cut off sediment supply to beaches alongshore (Runyan and Griggs 2003). Environmental problems are also sometimes related to beach nourishment works; nourished material usually increases water turbidity and sedimentation processes affect seagrass meadows and sediment quality in nearby beaches. As a result human activity on beaches generally produces loss of ecological value, decreases in biodiversity and diminution of landscape value (Williams and Micallef 2009). 
The case study presented here deals with the pitfalls of coastal armouring along $90 \mathrm{~km}$ of coastline including sandy beaches and cliffed sectors within the administration of the Ragusa Province (South Sicily, Italy). As observed in many Mediterranean countries (EEA 2006), coastal occupation in South Sicily has essentially been due to the tourism-related urban developments. Summer houses, apartments, hotels, restaurants, promenades and seafront roads have been constructed on the wide backbeach and dunes. In addition, ports, harbours and breakwaters have interrupted longshore drift and caused erosion of downdrift beaches (Cooper et al. 2009).

In this study, the coastline, defined as the instantaneous water line position (Boak and Turner 2005), as well as coastal defence structures, ports and harbours have been mapped using different cartographical series: a georeferenced topographic map (1967, scale 1:25,000), two registered and geometrically corrected photogrammetric flights (1977 B\&W, scale 1:17,000 and 1987 colour, scale 1:12,500), the 1999 orthophotographs series and, finally, the 2008 geographic data provided by the STIR Web Mapping Service (http://www.sitr.regione.sicilia.it).

Coastal evolution was calculated following the "end point rate" method (Jiménez et al. 1997) between successive photographs and the 1977-2008 interval, the investigated time spans corresponding to short and medium-term evolution according to Crowell et al. (1993). The total shoreline mapping error due to the geometrical accuracy and spatial resolution limitations of the photographs, and the uncertainty in water line position, has been assumed to be $10 \mathrm{~m}$. Consequently, coastal variations lower than $10 \mathrm{~m}$ and beach surface variations less than $2,000 \mathrm{~m}^{2}$ (calculated along longshore sectors $200 \mathrm{~m}$ in length), have been discarded and are not displayed in the final cartography (Martínez and Anfuso 2008).

For the quantitative assessment of human-made structures' impacts on the study area, coastal structures were mapped as line segments and the coefficient of infrastructural impact K (Aybulatov and Artyukhin 1993) was obtained by dividing the total length of all maritime structures (groins, moles, seawalls, revetments, breakwaters, etc.) by the entire length of the coastal section under consideration (in this case coastal sectors were $500 \mathrm{~m}$ in length). According to this methodology the extent of infrastructural impact could be then classified as minimal at $\mathrm{K}=0.0001-0.1$; average when $\mathrm{K}=0.11-0.5$; maximal at $\mathrm{K}=0.51-1.0$ and extreme, when $\mathrm{K}>1.0$.

\subsection{Study Area}

The study area is in Ragusa Province, South Sicily (Italy, Fig. 13.1). The littoral zone is composed of sandy beaches rich in quartz $(\cong 65 \%)$, carbonates $(\cong 30 \%)$, feldspars and heavy minerals. The beach face and nearshore areas have a low gradient and consist of fine sand with bathymetric contours running parallel to the coastline. One or more longshore bars are frequently observed and they 

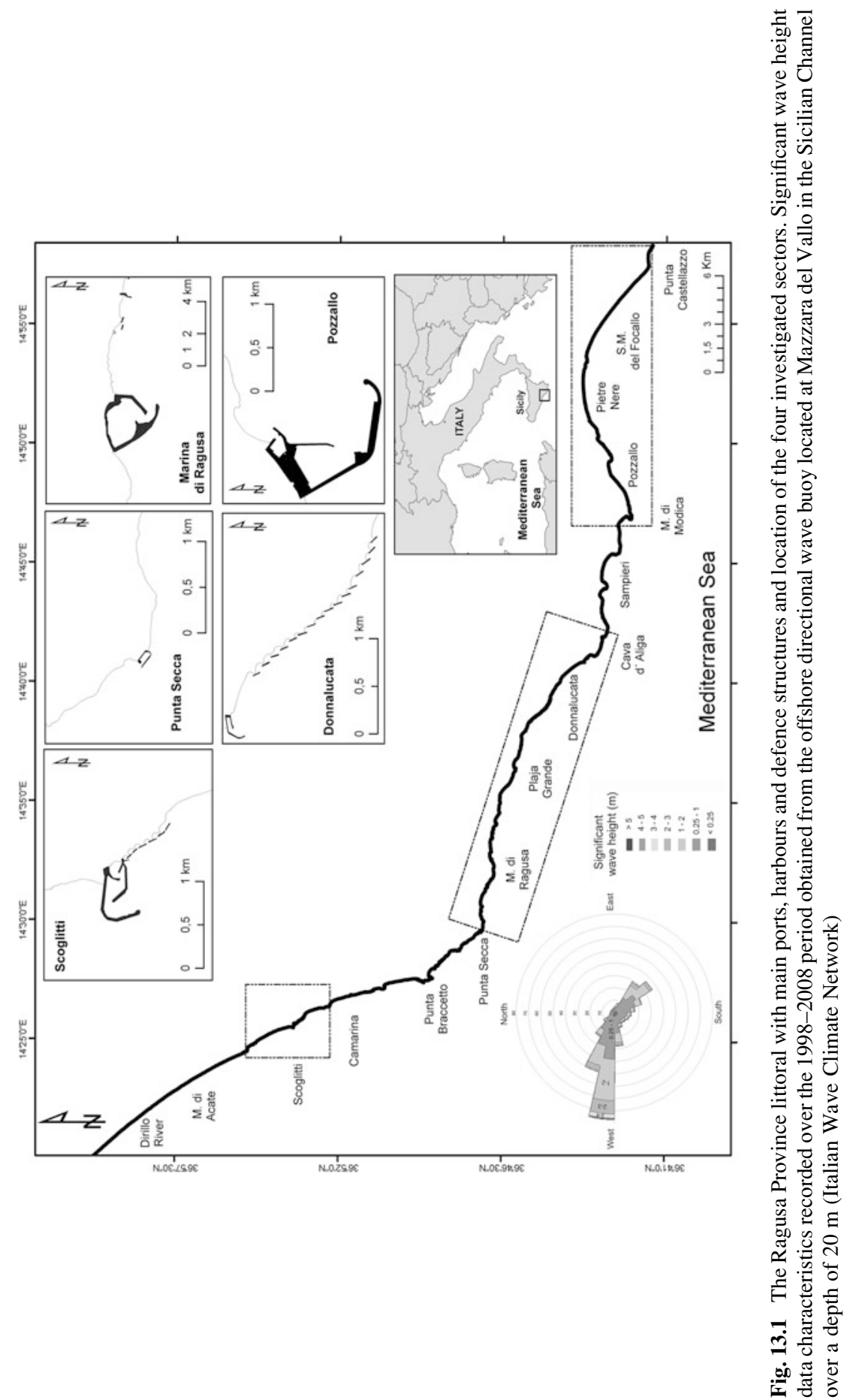
control breaking wave processes which usually take place far from the shoreline, giving rise to large surf zones with spilling breakers that are typical of dissipative beach states. Beaches are backed by dune ridges and cliffs while promontories divide the littoral into morphological cells. In most cases, sediments produced by cliff retreat are very fine and are rapidly winnowed by waves and there is no significant sedimentary input to the littoral budget from fluvial sources (Martínez and Anfuso 2008).

The study area is microtidal (astronomical spring tidal range c. $20 \mathrm{~cm}$ ), with prevailing winds from the $\mathrm{W}, \mathrm{SW}$ and SSW. According to the data from the nearest offshore buoy, most frequent and severe storms approach from the W and WNW with significant wave heights greater than $5 \mathrm{~m}$. Less severe storms approach from the SE, with maximum significant wave heights of $3 \mathrm{~m}$ (Fig. 13.1).

Because of its coastal orientation, the sector between the Dirillo River mouth and the Punta Secca promontory is essentially affected by storms from a westerly direction and the sector extending from the Punta Secca to the Punta Castellazzo promontories is influenced by storms approaching from the east and west directions, which give rise to important longshore currents. The main longshore transport along the Ragusa Province littoral is southeast directed but an opposite transport is also recorded, especially during spring and autumn. As a result of the coastline orientation, the westward directed transport is especially significant in the sector between Cava d'Aliga and P. Castellazzo (Fig. 13.1).

Along the investigated littoral, ports, harbours, coastal protection structures and headlands acquire a great importance in coastal compartmentalization because they work as convergent, divergent or transit limits (terminology following Carter 1988) dividing the littoral into morphological cells.

Since the 1960s ports and harbours have been constructed at Scoglitti, P. Secca, Marina di Ragusa, Donnalucata and Pozzallo. Rope haulage zones have been constructed at Casuzze, Sampieri, Marina di Modica and Pozzallo, and small, pre-existing agricultural and/or fishing villages have seen great expansion linked to the construction of summer houses and local tourism. The coastal population peak is recorded in July and August, when people move to the coast from the hinterland, generating a significant environmental pressure, i.e., increased demand for water supplies, sewage disposal, etc.

In terms of land occupation, increased human pressure on the coast has also occurred through the development of intensive agricultural activities. The lack of a management policy and the huge and rapid increase of human occupation resulted in urban sprawl and considerable coastal stress. In fact, most human activities and construction have been developed within the "protection" and "influence" zones defined by the Italian Coastal Act (2004). Within the protection zone, extending $150 \mathrm{~m}$ landward, any kind of construction is supposedly prohibited, and within the influence zone, which is $150 \mathrm{~m}$ landward extended, any construction needs to be approved by the local Planning Office. A management response is now required to protect coastal and, specifically, beach resources upon which the local economy is based. 


\subsection{Coastal Evolution and Armouring}

The study area can be regarded as a single large physiographic unit divided into several cells of different dimensions, limited by fixed, natural and artificial boundaries. In the study area, sediment broadly moves from west to east because of longshore transport which impinges on natural and human-made coastal structures, giving rise to a series of accreting/eroding areas. Hence, over the analysed intervals, significant areas of accretion have been observed close to harbours and ports, usually on the western sides of these structures, with erosion processes prevailing downdrift (Martínez and Anfuso 2008; Anfuso and Martinez 2009). This situation is evident at Scoglitti, Marina di Ragusa and Pozzallo ports and Donnalucata harbour.

All of these ports and harbours have experienced sediment infilling because their entrances are located within the surf zone. In an effort to solve the infilling problems, their jetties have been extended several times. This has simply exacerbated downdrift erosion, which in turn has been countered by the progressive construction of offshore breakwaters. These have locally halted coastal retreat giving rise to tombolo formation and the creation of a series of swash-aligned shoreline cells but they have also shifted erosion processes downdrift. The progressive addition of engineering structures to counter the problems caused by others has been termed the "domino" effect (Cooper et al. 2009). Coastal defences have been progressively emplaced over the investigated period with an associated increase in coastal armouring. In this paper, the impact of coastal structures and coastal armouring are assessed particularly in four coastal sectors: P. Zafaglione-Scoglitti (Fig. 13.2); P. Secca-Plaja Grande (Fig. 13.4); Playa Grande-Cava d'Aliga (Fig. 13.5); and Pozzallo-P. Castellazzo (Fig. 13.7).

In the P. Zafaglione-Scoglitti sector (Fig. 13.2), Scoglitti is a tourist coastal town with 3,000 and 66,000 inhabitants during winter and summer months, respectively. It is served by a port, essentially devoted to fishing activities. The port jetties have been modified several times since the 1960s (Fig. 13.3a) and the northern dock was enlarged again in 2008, at a cost of ten million Euros, converting the structure into an absolute cell limit that totally impedes sediment bypass.

Between 1987 and 1999 the port jetties created huge updrift accretion with c. $42,000 \mathrm{~m}^{2}$ of new formed beach surface (corresponding to shoreline advance of c. $10 \mathrm{~m} /$ year). A further increase of c. $15,000 \mathrm{~m}^{2}$ (c. $1.8 \mathrm{~m} /$ year) occurred in the 1999-2008 period and a total accretion of c. 55,000 $\mathrm{m}^{2}$ was recorded over the 1977-2008 period (c. 4 m/year), (Fig. 13.2).

Accumulated sediments are not removed by waves from the second and third quadrants, thus increasing the sedimentary deficit along the area between P. Zafaglione and Scoglitti port. This sector shows coastal squeeze-related problems, in fact it is constituted by a narrow sand beach backed by a cliff that is unable to migrate landward because it is artificially stabilised in order to protect the promenade and coastal road. In recent years, erosion processes have caused beach loss and rock falls in the backing cliff that was then additionally protected by rip-rap revetments and seawalls (Fig. 13.3b). 


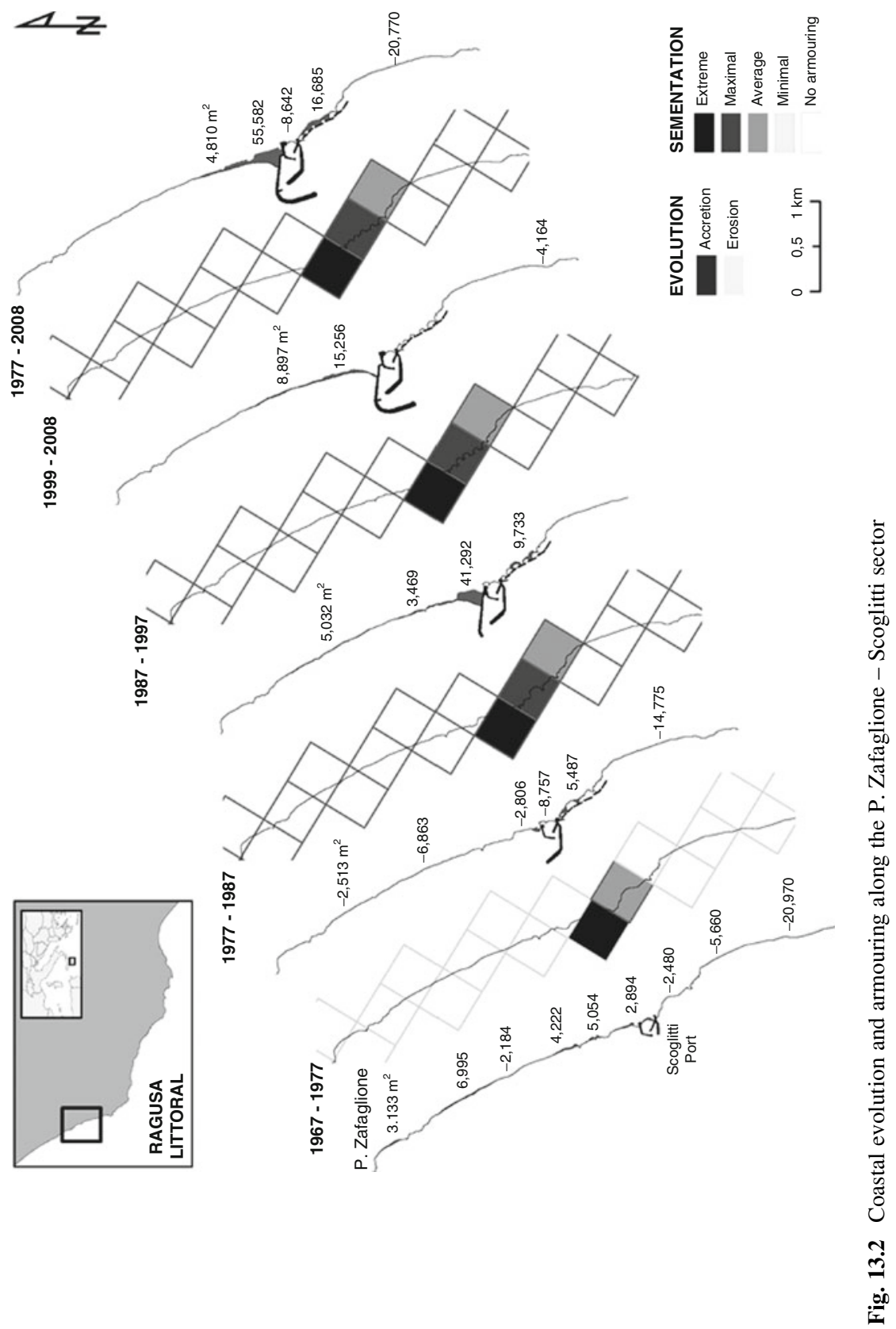



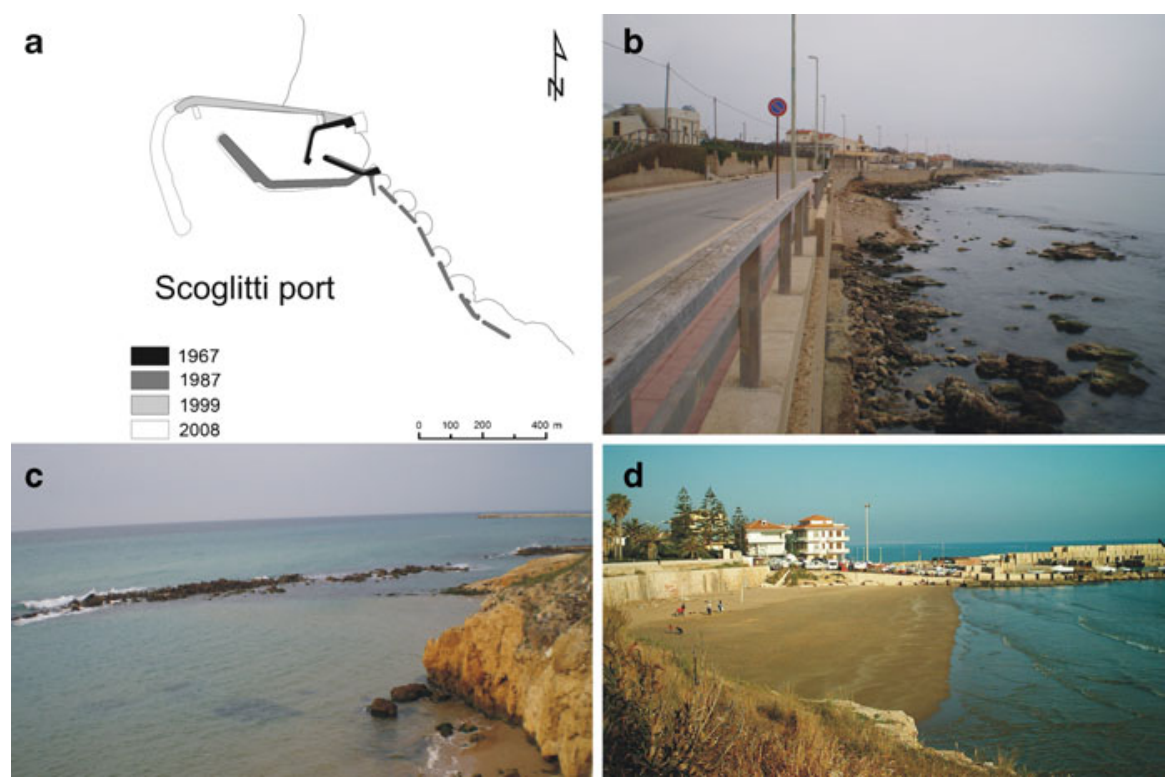

Fig. 13.3 Phases of Scoglitti port enlargement (a); littoral sector between P. Zafaglione and Scoglitti port, view from north to south (b, December 2010); southern breakwaters emplaced downdrift (south) of Scoglitti port (c, December 2010) and beach accretion updrift (west) of the dock and haulage zone at Marina di Ragusa (d, April 2006)

South of Scoglitti port (downdrift), six breakwaters have been progressively constructed to 'solve' erosion problems that then migrated further downdrift (southward) and affected the coastal road which is now protected by a rip-rap revetment.

Coastal armouring evolution reflected the progressive emplacement of structures; armouring was "extreme" in 1977, because of the port, and "extreme" to "average" in 1987 because of the construction of six offshore breakwaters. In the following decade, the northern breakwaters favoured tombolo formation while the southern ones suffered great erosion and did not form tombolos (Fig. 13.3c).

In the P. Secca-Plaja Grande sector (Fig. 13.4), the small harbour at Punta Secca produced accretion on the eastern side and recorded infilling problems. Approximately $12,000 \mathrm{~m}^{3}$ of sediments were trapped in the harbour over the 1985-1995 period.

At Marina di Ragusa, one of the most important tourist coastal towns in the study area, a dock and a haulage zone for small recreational boats were emplaced in the 1970s. The dock produced accretion updrift (west, Fig. 13.3d) and erosion downdrift (east) which was counteracted by the successive emplacement - over the 1987-1999 period - of two 70 m large breakwaters and few small groins which gave rise to a heavy swash aligned coastline.

At M. di Ragusa the new port, inaugurated in July 2009, is already suffering infilling problems and producing accretion at both sides of the structure, working as a fixed, convergent limit (Fig. 13.4). Erosion areas have been observed between 


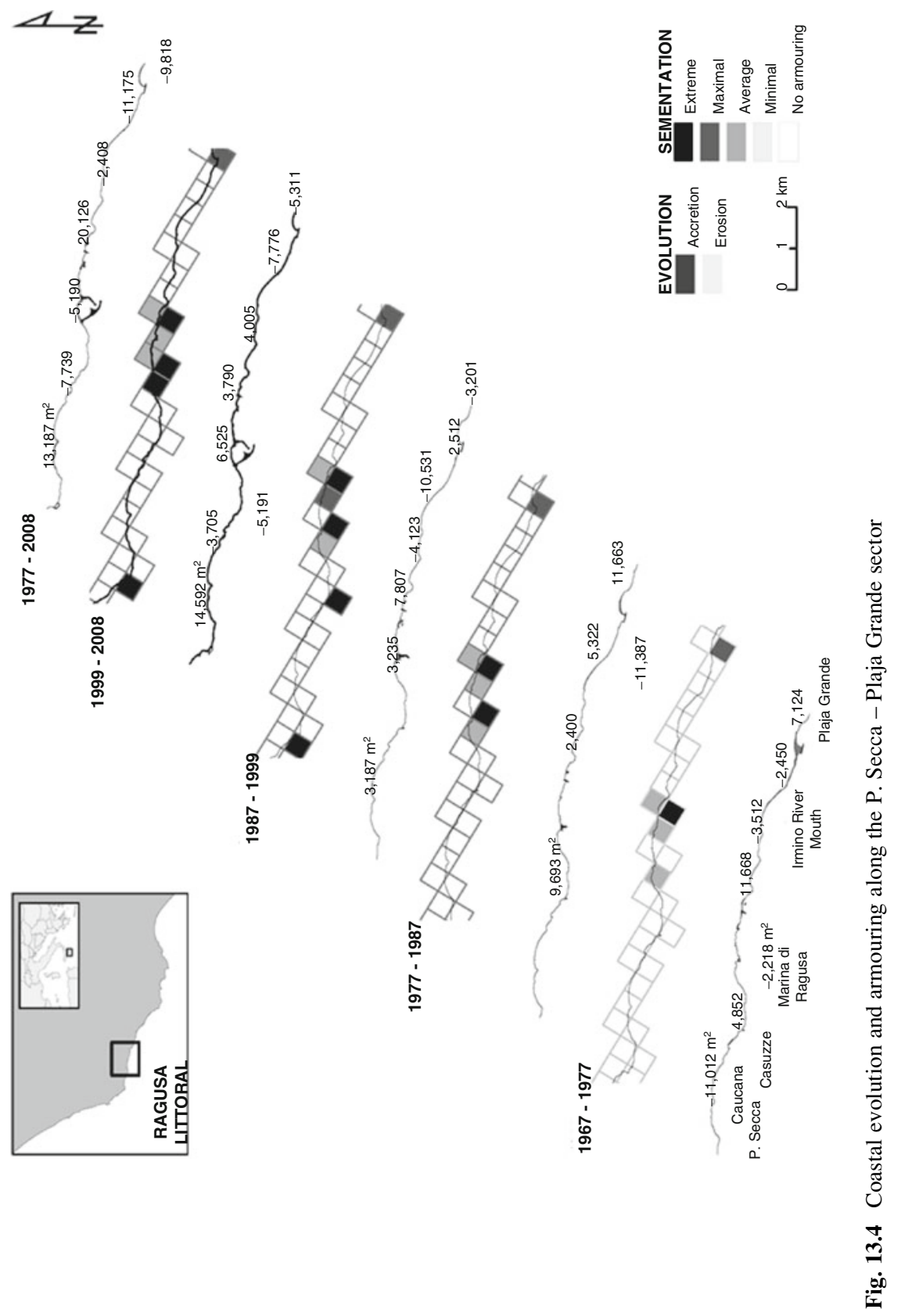


Punta Secca harbour and M. di Ragusa port, namely at Casuzze and Caucana; in the latter locality, $70,000 \mathrm{~m}^{3}$ of gravel was nourished in 2004 along an $800 \mathrm{~m}$-long coastal sector to protect Byzantine archaeological remains and the coastal road. In order to increase the stability of the artificial beach four submerged groins of calcareous rock blocks were emplaced. On the eastern side of M. di Ragusa port, a large artificial beach (c. $6,000 \mathrm{~m}^{2}$ ), protected by two submerged breakwaters, was created with sediments dredged during port construction. Dredged sediments, which came from Caucana and Casuzze areas, were taken from their original cell in this way and transferred to the adjacent morphological cell, between M. di Ragusa port and Donnalucata harbour.

Increasing erosion problems were observed between Marina di Ragusa port and Donnalucata (Fig. 13.4), especially in the Natural Protected Area located at the Irminio River mouth, where sand was winnowed and the underlying deposits outcropped (c. 12,000 $\mathrm{m}^{3}$ was lost between 1977 and 2008). At Plaja Grande, where a $240 \mathrm{~m}$ long breakwater was emplaced over the 1967-1977 and 1977-1987 periods c. $60,000 \mathrm{~m}^{2}$ (c. $3.5 \mathrm{~m} /$ year) and $16,000 \mathrm{~m}^{2}$ (c. $1.8 \mathrm{~m} /$ year) of beach accretion was recorded, respectively. Presently, the breakwaters form a swash-aligned shoreline impounding large quantities of sediments that are definitively lost to the longshore transport system.

Within the Plaja Grande-Cava d'Aliga sector (Fig. 13.5), Donnalucata is a small coastal village with c. 10,000 inhabitants during summer time, served by a small jetty in 1967. In 1977 this was extended and an additional one was constructed beside it to create a small harbour for fishing and recreational activities. The western and eastern beaches were linked by shallow offshore bars along which longshore transport took place, thus allowing periodic bypassing between the beaches.

Between 1967 and 1977 c. $19,000 \mathrm{~m}^{2}$ (c. $4.1 \mathrm{~m} / \mathrm{year}$ ) of new beach were formed and erosion was counteracted by the progressive construction of 16 breakwaters that again produced downdrift migration of the erosion problems according to the "domino" effect.

Between 1977 and 1987, in response to sediment accumulation in the harbour, principally linked to sediment and algae deposition by waves approaching from the second quadrant, the docks were extended and the updrift beach accreted and rotated as it adjusted to the new configuration. On the downdrift side, substantial erosion threatened the beachfront houses east of the main town and 16 offshore breakwaters were constructed. Great quantities of sand then accumulated in the lee of the offshore breakwaters forming a series of tombolos; as a result, east of the last breakwater, the coastline suffered erosion at spatially variable rates ranging between 1 and $5 \mathrm{~m} /$ year.

Between 1987 and 1999 the groins were extended again in response to continued sediment accumulation in the harbour. This led to further accretion in the beach to the west (c. $30,000 \mathrm{~m}^{2}$, c. $6.6 \mathrm{~m} / \mathrm{year}$ ), the gain of sediment is likely to be derived from longshore drift coming from the east, especially the Irminio River mouth area. The same trends continued during the 1999-2008 period and, when considering the 1977-2008 period, the sediment gain around the offshore breakwaters (c. $90,000 \mathrm{~m}^{2}$ ) equalled that lost from the area to the east (c. $92,000 \mathrm{~m}^{2}$ ). Accretion 


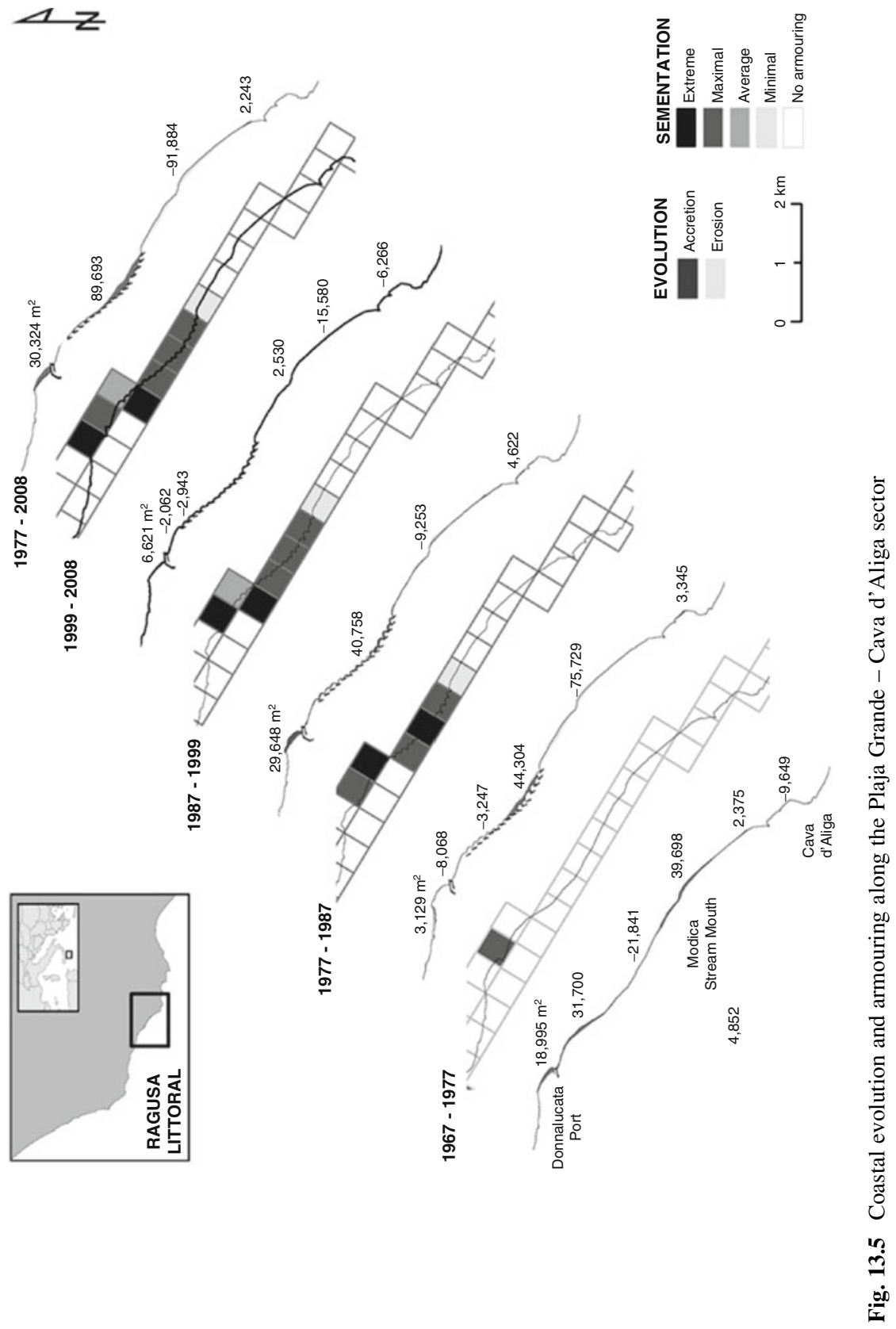



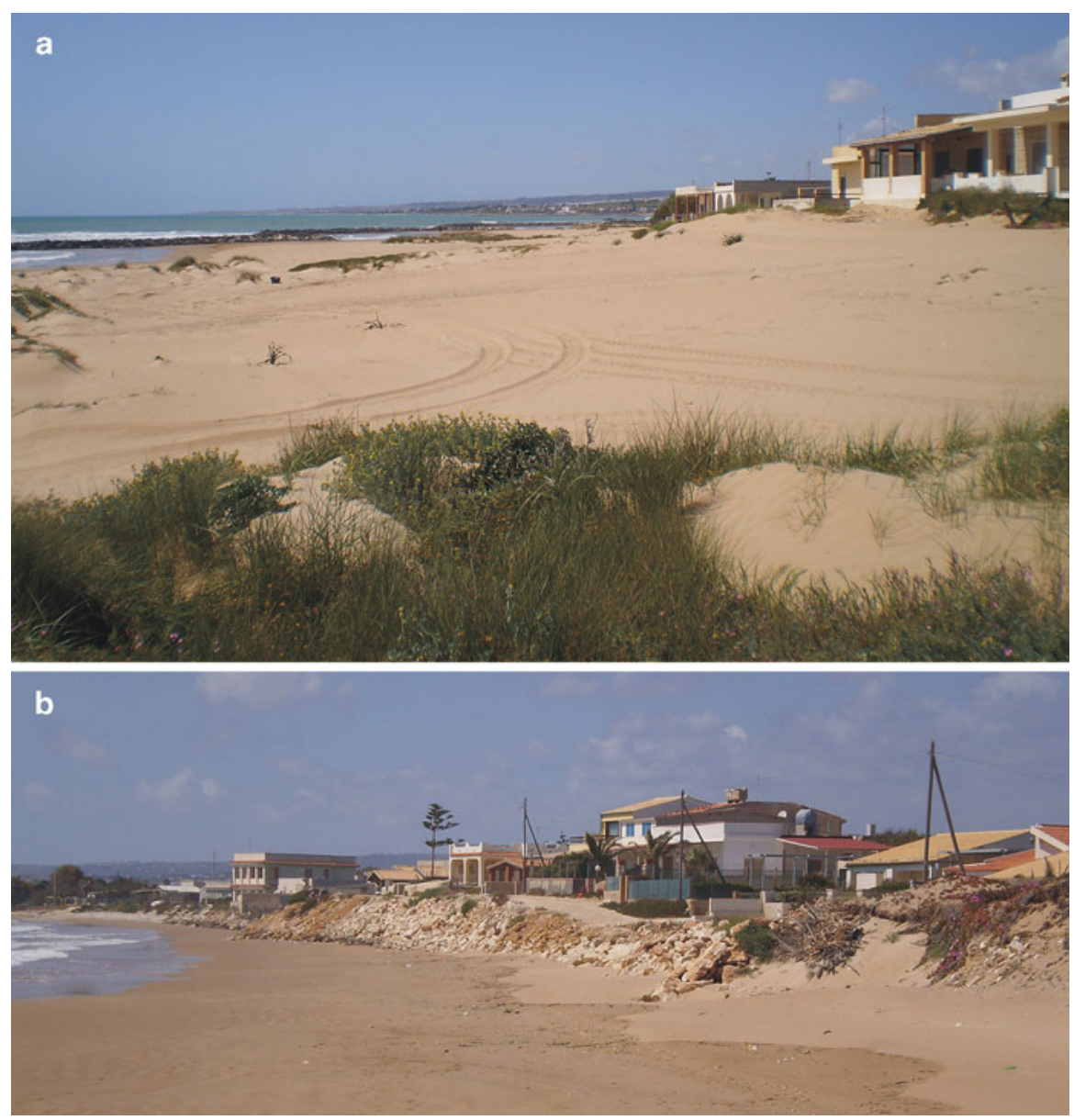

Fig. 13.6 Migrating dunes at the northern breakwaters emplaced downdrift (east) of Donnalucata harbour (a, April 2011); summer houses protected by rip-rap revetments downdrift (east) of easternmost breakwater at Modica Stream mouth (b, April 2011)

in the lee of offshore western breakwaters produced an important surplus of sediments which gave rise to the formation of landward migrating foredunes at places threatening summer houses and invading agricultural areas (Fig. 13.6e). East of the breakwaters extensive erosion processes reduced the beach width and a series of seawalls and rip-rap revetments were constructed to protect beach front properties (Fig. 13.6f).

At Donnalucata, the extent of coastal armouring was greatly increased and extended eastward; the amount of armouring slightly decreased over the 1987-1999 period because of the progressive formation of tombolos in the lee of the breakwaters.

In the Pozzallo-P. Castellazzo sector (Fig. 13.7), human impacts were related to the modification of Pozzallo pier and to the breakwaters constructed at Pietre Nere 


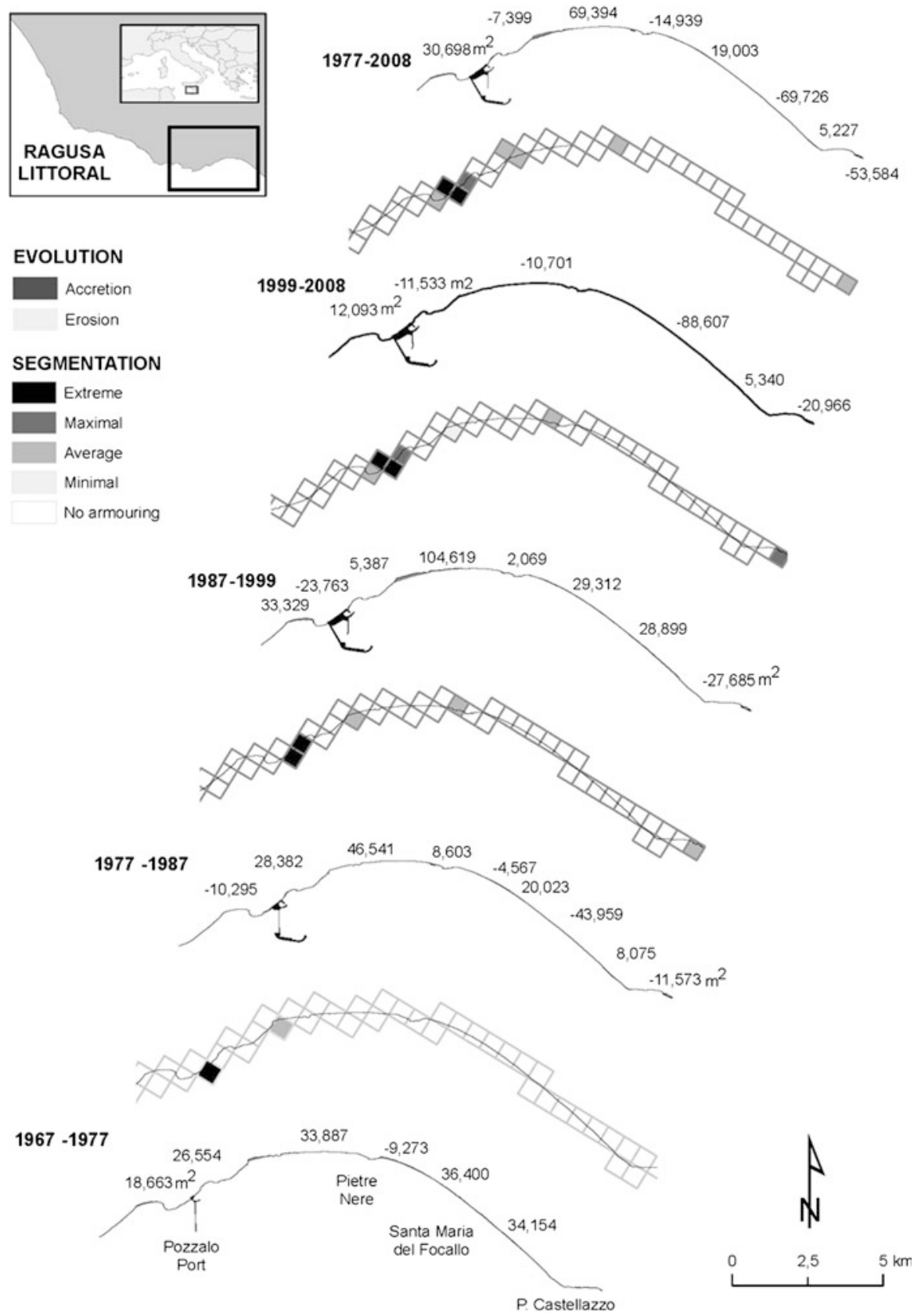

Fig. 13.7 Coastal evolution and armouring along the Pozzallo - P. Castellazzo sector 
and P. Castellazzo. Pozzallo is the most important coastal town in the Ragusa Province with a permanent population of c. 17,500 inhabitants. The town, which has a long maritime tradition, is served by a port constructed in the 1970 s to support the developing industrial activities. It originally comprised an offshore dock joined to the mainland by a pier which did not greatly affect littoral drift. In the 1980s, however, it was modified by the construction of a new east pier in order to protect the structure from waves coming from the third quadrant. Currently, this structure, which is still underused, is divided into different sectors devoted to recreational and fishing boats and cargo ships.

Because of the coastline orientation, wave fronts approaching from the second quadrant are of great importance and interact with the Pozzallo port to favour progressive and increasing sedimentation on the eastern side. As a result of this infilling, formerly deep water in front of the cliffed coastal sector is now very shallow and the urban beach of Pozzallo recorded an accretion of about $100,000 \mathrm{~m}^{2}$ of beach surface (c. 7 m/year) over the 1987-1999 period after the modification and enlargement of the port structure. Tourism developments, i.e. bars, restaurants, beach facilities and a promenade, have been constructed on the recently-formed beach.

Sediments impounded east of the Pozzallo port are not sheltered from western approaching waves because on the lee side of the port erosion processes were observed at Pietre Nere (where a $150 \mathrm{~m}$ long breakwater was emplaced) and at Santa Maria del Focallo, where coastal retreat affected the littoral road that was protected by concrete blocks. Over the 1999-2008 period, about 88,000 $\mathrm{m}^{2}$ (c. $3.2 \mathrm{~m} /$ year) of beach surface reduction took place at $\mathrm{S}$. Maria del Focallo (Fig. 13.5).

Lastly, four breakwaters were emplaced at the eroding cliffs forming the P. Castellazzo headland in order to preserve archaeological sites. The breakwaters caused an increase in beach surface area and the formation of tombolos that in subsequent decades experienced successive cyclic faces of erosion and accretion.

\subsection{Coastal Structure Impacts and Management Policies}

The observations show that beach behaviour is not primarily impacted by coastal dynamics but by ill-placed developments constructed since the 1960s. Coastal infrastructure includes beachfront summer houses, restaurants, coastal roads and greenhouses and all of these greatly affect beaches and dunes (Fig. 13.8a, b). The extension of ports and harbours initially designed for recreational and small-scale fishing activities (at P. Secca, Marina di Ragusa and Donnalucata) or fishing and commercial activities (at Scoglitti and Pozzallo) have also had significant impacts.

The ports have suffered from an unsuitable location in terms of hydrodynamics and poor design and they have experienced problems through accumulation of sand and Posidonia Oceanica debris and cannot be used for long periods. For instance, at Donnalucata, during 2007, the harbour was totally filled by algae and sand and 

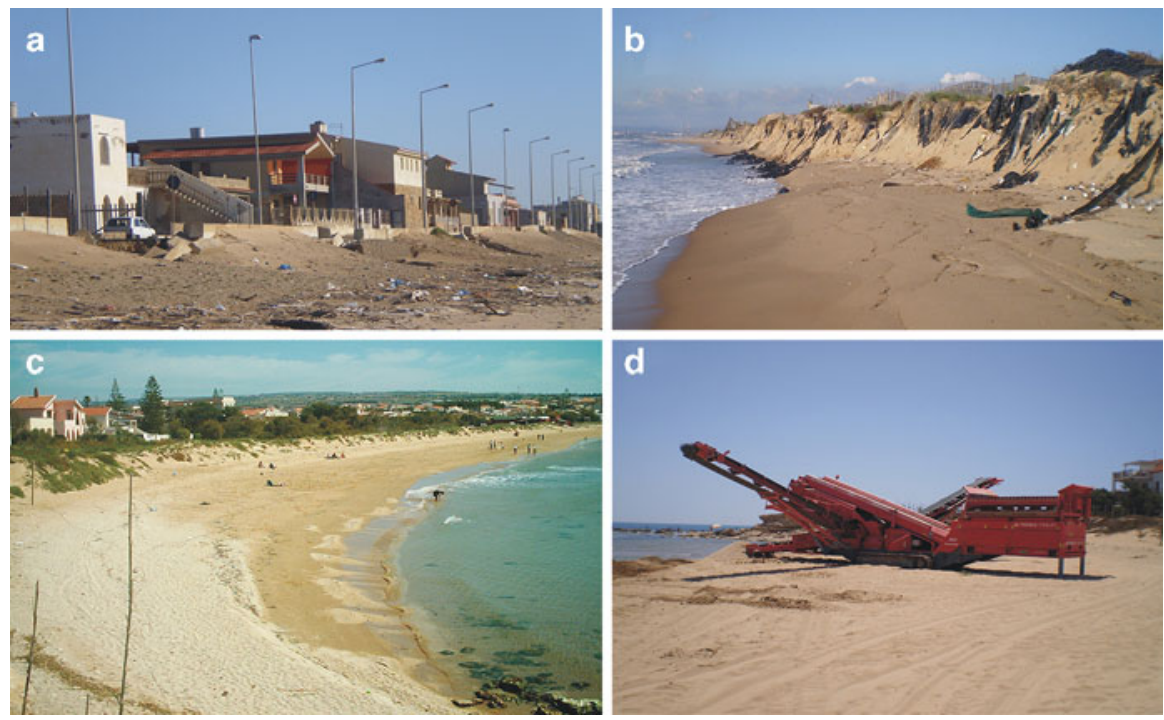

Fig. 13.8 Beach erosion and damages caused by run off processes at M. di Acate (a, December 2010); environmental degradation associated with greenhouses north of $\mathrm{M}$. di Acate (b. December 2010); white gravel sediments coming from the nourished sector at Caucana (c, April 2006) and the mechanical machinery used in the attempt to remove gravel sediments (d, July 2010)

was completely useless; a similar situation presently exists at the Pozzallo port sector for recreational boats.

In order to solve infilling problems, port docks were elongated several times which exacerbated downdrift erosion while periodically dredged sediments - that could have been used for beach nourishment or just bypassed downdrift - were accumulated in city dumps or deposited offshore (Anfuso and Martinez 2005).

All of the ports and harbours and the breakwater at Plaja Grande gave rise to wide beaches but only a c. $50 \mathrm{~m}$ wide strip close to the shoreline is used by bathers, most of the beach surface being unused or only partially occupied by tourist developments, especially restaurants and beach facilities. Hence, beach users and Municipalities acquired some minor benefits from beach surface accretion at specific sites. The opposite is true in eroding areas. Erosion processes at Santa Maria del Focallo (Ispica Municipality) reduced the beach surface area, diminished the beach attractiveness and reduced tourism demand, and created additional expense to repair the damaged coastal road and construct protective structures. The eroded sediments accumulated at Pozzallo town where the newly enlarged beach presently hosts a number of economically beneficial activities for the local residents and the Municipality.

The term 'coastal protection' means different things to different people (Cooper and McKenna 2008; McKenna et al. 2008). To environmentalists and ecologists it means letting nature take its course to protect the ecosystem while to coastal 
landowners and engineers it means constructing something to protect property. The latter interpretation is prevalent along the Ragusa littoral. But the protection is successful only if its impacts are disregarded. These are, however, usually very high in socio-economic, demographic, ecological, physical and climatic terms (Fabbri 1998).

The use of science in environmental decision-making has not increased over past decades, thus resulting in a huge knowledge gap between scientists and decision makers (O'Connor et al. 2009). The main problems which prevent the integration of science into the environmental decision-making are uncertainty surrounding scientific information, unusable scientific information and lack of active and continuous communication between different actors (O'Connor et al. 2010). This has been true through recent decades in Sicily, where no relation at all existed between scientists and managers, and a general management plan was never implemented. Nowadays, some improvement is taking place in this sense because of the development of environmental studies, collaborations with research entities and the formulation of general guidelines for ICZM (Integrated Coastal Zone Management) at a regional level.

Despite the existence of the aforementioned guidelines, beach protection and erosion management were transferred in 2010 from the Provinces to the Municipalities that only have a very local view of erosion problems and quite often lack the technical capacity for proper coastal management decision-making.

The response of policy-makers and managers in Sicily to coastal erosion suggests a concern for short-term human interests over long-term strategic goals despite the fact that strategic goals in ICZM should prevail over local ones. McKenna et al. (2008) show that there is still sufficient flexibility in European ICZM recommendations to justify advancing the self-interest of individuals or small groups at the expense of the public good or long-term sustainability. Generally, the local principles, based on small spatial and/or temporal perspectives, greatly reflect the bottom-up participatory, consensus-based approaches in ICZM at the expense of generic, strategic principles. In Ragusa decision-making is not based on bottom-up community participation. Rather, decisions are taken at a personal level, because of very specific political or economic interests and often breakwaters were emplaced under the guise of "urgent" conditions that allowed Administrators to order their construction without following the normal legal procedures, e.g. public procurement.

This case study shows a common sequence of events where one unwise action is countered by another, which in turn creates more problems. This was because of a weak system of regulation, strong political interference and ignorance (or indifference) of the implications of the environmental impacts of human interventions. The analysed situation was exacerbated by a public perception that government had a duty to protect private property, a situation that has been noted elsewhere in Europe (Cooper and McKenna 2008).

As a result, the massive engineering interventions at Donnalucata were precipitated by unplanned and illegal constructions (illegal in the sense that they do not conform to planning regulations) of beachfront summer houses and greenhouses for intensive agriculture. Without the presence of these illegally built structures, there would have been no need for publicly funded intervention. The degradation caused 
by efforts to defend the interest of a small number of stakeholders is not only suffered by society in general, through loss of environmental quality and amenity and public funding of defence structures, but also by nearby stakeholders whose (downdrift) properties became at risk after the emplacement of structures (Cooper et al. 2009). Similar situations were observed at Scoglitti, Marina di Ragusa, Plaja Grande and Pietre Nere, where breakwaters were successively constructed to enlarge beach width provoking downdrift erosion.

Hence, the shoreline stabilization 'solutions' did not solve the problem but just treated the symptoms and, in many cases, produced side effects which created additional problems, the most important being downdrift erosion. Furthermore, at the medium-term scale, coastal structures prevent landward migration and inhibit beach-dune and beach-shoreface interactions which are especially important during extreme events. They increase coastal squeeze, which requires more hard structures and/or greater nourished sand volumes for beach maintenance under sea level rise conditions (Cooper and Alonso 2006). This is a common problem at many places in the study area as well as in many other Mediterranean coastal sectors where beaches have been transformed into "sandy solariums" and are experiencing continuous and constant deterioration, under the perception that a beach is similar to a golf camp or a playground which need continuous maintenance. In such situations, humans are the primary geomorphic agent and beach construction and maintenance depend on human interventions. This creates a dramatic rise in expense for maintenance as even more infrastructure is built at the coast.

Additional problems associated with the emplacement of coastal protection structures are the increased risk of drowning and the negative impact of structures on coastal scenery (sensu Williams and Micallef 2009), especially evident at Donnalucata where breakwaters create a major visual impact.

Beach nourishment works at Caucana in 2004 may produce severe consequences on seagrass beds, which have a great ecological value and reduce the energy of incoming waves. The seagrass areas form the natural source of calcareous skeletal debris that at places comprises up to $80 \%$ of the natural beach sediment (Garcia and Servera 2003). At Caucana, nourished sediments essentially consisted of coarse sand and gravel obtained by crushing the local Miocene limestone (the Ragusa Formation) with a cost of $12 € / \mathrm{m}^{3}$ and a total cost for the nourishment works of two million Euros. High water turbidity was observed during the nourishment works and for a few months afterwards particularly during energetic wave conditions. Under these conditions, sediments are deeply remobilised and the white silt-sized fraction is suspended. The silt-sized fraction is linked to the crushing process and also to the abrasion process, which progressively rounded and reduced the size of the injected sediments.

At present, gravel sediments are partially covered with sand and the problems of turbidity previously described did not impact the sea-meadows fronting the nourished beach sector. On the other hand, in 2005 nourished sediments started to bypass the eastward artificial submerged groin and arrive at the adjacent beach (Fig. 13.8c). This produced great discontent among beach users and pushed the local Municipality into a ridiculous attempt, carried out in July 2010, to remove 
the gravel which by that time was deeply mixed with the natural sand along the whole beach length (Fig. 13.8d).

Other beach nourishment works are projected for several sectors in the study area. Most important problems linked to the execution of such projects are the availability of suitable borrow material in land deposits, because no geophysical surveys have been carried out to identify marine sources. Furthermore, the idea of using sediments trapped updrift, or within ports and harbours, for nourishment projects as well as the idea of placing permanent bypassing systems, have not been considered.

Lastly, several economic considerations emerge when analysing the solutions adopted to counteract coastal erosion problems over the past decades. On one side, the huge costs associated with beach nourishment and construction and maintenance of hard structures were mainly supported by the Regional Government through European Regional Development Funds. On the other side, income from property taxes and other revenue generated by coast-dependent tourism was gained by local Municipalities. Furthermore, the cost of the protective structures is quite high when compared with the economic returns from beaches, essentially consisting of activities, such as the renting of summer houses, which do not contribute taxes.

According to the previous assumptions, hard structures and nourishment operations at many places along the Ragusa littoral are probably only partially economically justified. An exhaustive cost-benefit analysis should be carried out because such analyses give a reliable basis for decision-making processes in coastal erosion management.

Acknowledgements Thanks go to Mike Scott (UBC Vancouver, Canada) for improving the quality of English and to Morris Floridia for field assistance. This work is a contribution to the Andalucía PAI Research Group RNM 328.

\section{References}

Anfuso G, Martinez JA (2005) Towards management of coastal erosion problems and human structure impacts using GIS tools: case study in Ragusa Province, Southern Sicily, Italy. Environ Geol 48:646-659

Anfuso G, Martinez JA (2009) Assessment of coastal vulnerability through the use of GIS tools in South Sicily (Italy). Environ Manage 43:533-545

Aybulatov NA, Artyukhin YV (1993) Geo-ecology of the World Ocean's Shelf and Coasts. Hydrometeo Publishing, Leningrad

Boak E, Turner I (2005) Shoreline definition and detection: a review. J Coast Res 21(4):688-703

Carter RWG (1988) Coastal environments. Academic, London

Cooper JAG, Alonso N (2006) Natural and anthropic coasts: challenges for coastal management in Spain. J Coast Res SI 48:1-7

Cooper JAG, McKenna J (2008) Working with natural processes: the challenge for coastal protection strategies. Geogr J 174(4):315-331

Cooper JAG, Anfuso G, Del Río L (2009) Bad beach management: European perspectives, vol 460, Geol Soc Am, Special Paper. Geological Society of America, Boulder, pp 167-179 
Crowell M, Leatherman SP, Buckley M (1993) Shore-line change rate analysis: long term versus short term data. Shore Beach 61(2):13-20

Doods R, Kelman I (2008) How climate change is considered in sustainable tourism policies: a case of the Mediterranean islands of Malta and Mallorca. Tour Rev Int 12:57-70

Doody JP (2004) 'Coastal squeeze' - an historical perspective. J Coast Conserv 10(1-2):129-138

EEA (2006) The changing face of Europe's coastal areas. In: Breton F, Meiner A (eds) EEA report no 6, Luxembourg office for official publications of the European Communities, Luxembourg

Fabbri KP (1998) A methodology for supporting decision making in integrated coastal zone management. Ocean Coast Manag 39:51-62

Garcia C, Servera J (2003) Impacts of tourism development and water demand and beach degradation on the island of Mallorca (Spain). Geogr Ann 85:287-300

Hanson H, Brampton A, Capobianco M, Dette HH, Hamm L, Laustrup C, Lechuga A, Spanhoff R (2002) Beach nourishment projects, practices, and objectives - a European overview. Coast Eng 47:81-111

Jiménez J, Sánchez-Arcilla A, Bou J, Ortiz M (1997) Analysing short-term shoreline changes along the Ebro delta (Spain) using aerial photographs. J Coast Res 13(4):1256-1266

Jones A, Phillips M (2011) Disappearing destinations. CABI, Wallingford

Klein YL, Osleeb JP, Viola MR (2004) Tourism generated earnings in the coastal zone: a regional analysis. J Coast Res 20(4):1080-1088

Martínez JA, Anfuso G (2008) Spatial approach to medium-term coastal evolution in south Sicily (Italy): implications for coastal erosion management. J Coast Res 24(1):33-42

McKenna J, Cooper JAG, O'Hagan AM (2008) Managing by principle: a critical analysis of the European principles of Integrated Coastal Zone Management (ICZM). Mar Policy 32:941-955

O'Connor MC, Cooper JAG, McKenna J (2009) Integrating science into shoreline management practice and policy: an Irish perspective. J Coast Res Spec Iss 56:1267-1270

O'Connor MC, Cooper JAG, McKenna J, Jackson DWT (2010) Shoreline management in a policy vacuum: a local authority perspective. Ocean Coast Manag 53:769-778

Pilkey O, Dixon K (1996) The corps and the shore. Island Press, Washington

Runyan K, Griggs G (2003) The effects of armoring seacliffs on the natural sand supply to the beaches of California. J Coast Res 19(2):336-347

Williams A, Micallef A (2009) Beach management, principles \& practice. Earthscan, London 